\title{
LEADERSHIP STYLES IN THE MANAGEMENT OF IGBO CULTURAL HERITAGE IN PRE-EUROPEAN ERA
}

\author{
Ngozi Ezenagu* \\ http://dx.doi.org/10.4314/og.v13i 1.2
}

\begin{abstract}
Leadership in most Igbo communities during the pre-colonial era was based on consultative assembly of the council of elders following after the then culture of the Igbos which does not recognize "kingship". The dominance of cultural precepts sustained the longevity of Igbo cultural heritage at that time. At present, these heritages are exposed to extinction with the importation of colonial vestiges into Igbo culture. Consequently, Igbo cultural identity is gradually disappearing. To redress this, it is imperative to study one of the management techniques "leadership style" under which these heritages flourished in the past. Therefore, this study focuses on leadership style most appropriate for the successful management of Igbo cultural heritage. The data used for the research were elicited from oral interview and other written literatures related to the subject matter.
\end{abstract}

Key words: Igbo, Pre-European era, cultural heritage, leadership styles, socio-political organisation

\section{Introduction}

Igbo or Ibo as used by most scholars represents both a group of people and a language stock with numerous dialects. This language is spoken by a group of people known as "Igbo people" geographically located in the south eastern region of Nigeria bound by culture. The Igbo people under study here is the Awka tribe. Originally spelt $O k a$ but with the introduction of English alphabet it is now spelt Awka. The first occupant of Awka land remains unknown. According to Mr.Nwaofor (2015) Awka people are sojourners from other Igbo tribes. To affirm this, Awka tribe is an amalgamation of Igbo sojourners merged into thirty-three (33) clans bonded by traditional beliefs and practices.

This ancient town $(O k a)$ in the pre-European era practiced an exceptional system of government with culture as the benchmark 
for governance. Culture being its way of life is intertwined with traditional religion creating divine sanction a means to guard the conduct of men. At this juncture, it's important to note that most preEuropean Igbo communities progressed without the existence of a central government. Illustrating this, Achebe (1983: 47) opined that beyond town or village the Igbo has no compelling traditional "loyalty" to anyone. In view of this, Igbos of pre-European era governed themselves independent of a king under the authority of the council of elders. This gave rise to the popular maxim "Igbo enweEze" meaning "Igbos have no king". Considering this system of governance most scholars described traditional Igbo community of pre-colonial Nigeria as a republican system of government. This system of government guaranteed the natives a fair say in community affairs through its delegated power to leaders of social institutions.

However, culture been the yardstick for governance over time yielded tangible and intangible historical legacies known today as cultural heritage (products of culture). These include arts and craft, songs, myth, oral traditions, traditional titles, dance, drama, festival and traditional technology among others. The above elements became the Igbo race marker of identity. The leader's incharge of these social institutions was subject to the authority of the council of elders. Therefore, the absence of a consensus leader in pre-colonial Igbo community never ruled out the role of a leader. Generally, leadership exists in all societies as no group can survive without the process of leadership. Therefore, leadership is an important resource of all societies and is exhibited by individuals through a broad scope of talents and abilities (Lester, 1975). The effectiveness of these leaders in preserving Igbo cultural heritage is dependent upon their leadership style. Each person's leadership style has an important bearing on the continuity of the Igbo race and its traditions. These leaders are custodians of cultural institutions to which the Igbo race owe its quintessence.

\section{Conceptual Literature: Leadership}

The word "leadership" is a universal phenomenon used in different aspects of human endeavour such as politics, businesses, academics, social works, organizations, management etc. It is a process through 
which a leader influences his followers in an effort to achieve stated objectives. This process according to Khan (2010) is vital for effective implementation of total quality management initiatives. Consequently, the future of any group rests upon the initiatives of the leader. Primarily, a leader is anyone who directs and controls a group of people to achieve set objectives. They are conceptualized as active players in the process of leadership (Ingo, 2010). Thus, leadership is a social influence process in which the leader seeks the voluntary participation of subordinates in an effort to reach organization goals (Omolayo, 2007). The successful accomplishment of set objectives in Bass (1989) view involves the application of leadership attributes, such as belief, values, ethics, character, knowledge and skills. Hence, the process of leadership cannot be separated from the personality of the leader. Adjudging the personality of the leader vital to the process of leadership Kets de Vries, (2001) defined leadership as:

a set of characteristics - behaviour pattern and personality attributes - that makes certain people more effective at attaining a set goal." But it is also a process, "an effort by a leader, drawing on various bases of power...to influence members of a group to direct their activities toward a common goal (Kippenberger, 2002: 7).

From the above citation one would observe that leadership is not all influence, also involved are certain attributes without which leading would be difficult. To effectively lead an organisation to achieve set goals it is imperative that the leader possesses well defined personality and capabilities. With the absence of these traits organizations may lose focus, stagnate, and eventually suffer the consequences of collapse.

However, leaders are categorized by different criteria and one of them is the style of leadership (Bosiok, 2013). Leadership style is one of the factors that played significant role in ensuring the attainment organizational goals. As Lester (1975) buttressed that different leadership styles aids the accomplishment of task and maintenance of functions of an organization. Bearing this in mind, 
different leadership styles may affect organizational effectiveness or performance (Nahavandi, 2002). Based on this, Oladipo et al, (2013) credited the success or failure of proper organizations, nations and other social units to the nature of leadership style.Primarily, leadership style is the, relatively consistent pattern of behaviour that characterizes a leader (DuBrin, 2001). In Lussier and Achua (2010: 7) opinion "it is a combination of traits, skills and behaviours that leaders use while they interact with subordinates". From behavioural view leadership style serves as a medium of interaction between the leader and the group. This interaction centres on decision-making which can be influenced by certain circumstances the leader has been exposed.

The subject "leadership style" is not a recent field of study. According to Kaiser and DeVries (2000) the earliest studies of leadership styles were conducted by Lewin and colleagues in the late 1930s (e.g., Lewin, Lippitt, \& White, 1939). The findings of their study identified three leadership styles: an authoritarian style (directing group activity through unilateral decision making and personal control), a democratic style (involving group members in decision making processes), and a laissez-faire style (passive and disengaged, exerting little influence). The entire study focused on decision making one of the ways through which a leader exercises authority over the subordinate. For Lewin et al, the nature of decision-making in an organization determines the leadership style adopted.

Also, another early study on leadership style was conducted by Likertin the 60s. From his study in 1967, he identified four styles of leadership. Foremost, the exploitative-authoritative style, where the leader has low concern for people and uses such methods as threats and other fear-based methods to achieve conformance. Secondly, benevolence-authoritative style where by the leader uses rewards to encourage appropriate performance and listen more to concerns lower down the organisation. Thirdly, consultative-style, the leader makes genuine efforts to listen carefully to ideas. And lastly, in participative-style, people in all level of organisation partake in decision-making thus are psychological closer and work well together at all levels. The leader's ability to adopt any style 
depends solely on his personality and circumstances within the organisation.

The above early studies on leadership style anchored on decision-making whereas in pre-European Igbo communities' decision-making is not the prime concern of leadership style. Since decisions in pre-colonial Igbo communities were draw from general consensus any leadership style adopted inculcates this characteristic. The focal point of leadership style of pre-colonial Igbo communities was on the longevity of Igbo cultural heritage. With traditions been the mainstay of Igbo cultural identity any alteration is usually resisted and avoided. Thus entrusting this vital aspect of Igbo existence to the decision of a single fellow was an unwelcome assumption. To this end, the leadership style adopted in the management of Awkacultural heritage in pre-European era was Likert participative style and the Lewin democratic style. Both styles synchronises with then system of governance where the council of elders ruled by consensus of opinions. The democratic and participative style also best describes the cultural environment wherein leaders were groomed. As earlier noted leadership style is influenced by numerous characteristics one of which is personality traits. Considering the environment of pre-European Igbo communities' leadership style represents the general attitude of a leader particularly in relation to the preservation of Igbo cultural heritage largely expressed through his traditional beliefs. Therefore, the effectiveness of leadership style in pre-European Igbo communities was measure by the continuity of the group.

\section{Cultural heritage}

Heritages constitute all the indispensible extinct and extant legacies of a community through which its continuous identity and uniqueness is preserved. These ranges from resources bequeathed by nature to the community in addition to that produced from the community's interaction with the environment. Natural heritages such as groves, rocks, mountains, etc are most times better appreciated based on cultural features. In the light of the above, the term heritage most times is referred to as cultural heritage considering the influence of human activities on natural sites. Therefore, heritages extend to living expressions inherited from 
ancestors and passed onto descendants. Concurring to the above Ozo-Eson (2012: 35) asserted that cultural heritage involves aspects of African social lives which are highly appreciated and valued by the society.

In view of this, Igbo cultural heritage comprises an amalgamation of their tangible and intangible cultural products. The tangible refers to the objects made by the people which played certain roles in the life of their life. They include monuments (statues, traditional architectural building etc) historical sites, art works, products of indigenous technology etc while the intangible are cultural patterns, socio-political organisations and norms such as dance, drama, folklore, oral tradition, festivals, etc. These heritages are important to the study of human history because they provide a concrete basis for ideas, and can validate them. Their preservation demonstrates recognition of the necessity of the past and gives people a literal opportunity access to the past. The importance of heritage goes beyond cultural manifestation to showcase the wealth of knowledge and skills that is transmitted through it from one generation to the next. The benefit of this knowledge transmission is a necessity for the continuity of any race. Therefore, heritage is the cultural mark of a people and those that survive to present are termed unique and irreplaceable which places the responsibility of its preservation on the community.

\section{Igbo political organisation in the pre-European time}

The political organisation of Igbo people before and during the European era in Nigeria is that of a society based on the "town" as an autonomous unit (Ogbalu, n.d) most times regarded classless by various authors. The absence of a consensus leader delegated administrative authority of the community to the council of elders. In view of this, Graham and Gunner (1995) noted that traditional Igbo political organization was based on a quasi-democratic republican system of government. Of which Ogbalu (n.d) concurred that it was republican in every aspect of the word. Anyanwu (1995) buttressed that with the self governance the presence of kingship in Igbo leadership is not only unwelcome and unacceptable but also unhealthy and anti-thetical to Igbo leadership principles, values and practices which were described as totally democratic and republican. 
As a result, before the European era there has never been either in myth, legend or in history anybody known as the king of the Igbos for the Igbos say "Igbo enweEze" (Igbo have no king).

The word 'king' translated to "Eze" and the process of kingship was not only strange to the Igbos but was not practised. Thus, the present usage of the word "Eze or Obi"meaning king in Igbo communities confirmed their contact with foreign cultures. Restricting the adoption of Ezeship - Kingship to foreign contact Ogbalu (n.d) observed that among western Igbos a little bit of certainty exists that the influence of Benin and Yoruba practices were responsible for the firm establishment of governmental system of Obiship by which each town had its own Obi as the head of its government and with attributes resembling those of some European Kings. For example, Onitsha town which claims to have come from Benin had a strong tradition of Obiship which is alien to Igbos town east of Niger and must be an exception together with certain towns west of the Niger. Nonetheless at present Mr.Anaje noted that even Awka town has also joined the bandwagon of Obiship. The crowned ruler is addressed "Eze-Uzu" "Eze" meaning "King" while "Uzu" means "Blacksmith" a trade with which Awka is renowned.

However, as earlier noted leaders are found everywhere of which the pre-European Igbo communities are no exception. At the peak of Igbo political hierarchy lies the Council of Elders which is made of members of each clan or family head, and titled men preferable $O z o$ tilted men been the most prestigious title in Igbo land. These reputable titled men were acknowledged for their transparency in traditional matters. Next are the spiritual intermediaries of the community - chief-priests of various shrines. They are the mediator between the people, gods and ancestors. They are also the custodian of morality and works directly with the Council of Elders. Following the chief-priests, are the traditional medicine men famous for their unique spiritual abilities in solving human problems. The Umunna (male members of a clan) oversees issues arising from the families and villages respectively while the Umuada (daughters of a clan) presides over domestic or family matters. The Masquerade is the police of the community. The Agegrade guards the community against the enemy invasion and also enforces law and order. Through the activities of the above named 
Ezenagu: Leadership styles in the management of Igbo...

persons of different social institutions the traditions of the land is sustained and preserved.

\section{Leadership style and the custodians of Igbo cultural heritage in pre-European time}

Leadership is one of the most observed and least understood phenomena on earth (Burns, 1978). It is an injunction conferred on man from the creation story of the universe following the Christian Bible where God gave man dominion over the earth (Genesis 1:26). By nature man is a leader subduing his environment at will. Over the decades Africa possess records of man's leadership expedition notably the Portuguese exploration and the colonial experience of Nigeria experience.

However, today the attainments of certain goals are dependent on the leader and his leadership style. Stogdill (1974) asserted from his research findings on leadership that both animal and human social system indicates that the rigor and survival capacity of a group are closely dependent upon a type of leadership that is able to maintain its integrity, drive and goal direction. This implies that the effective management of a group solely depends on the style of leadership adopted by the leader in achieving the goals of the group. The proper management of Awka cultural heritage was tied to leadership style which in most cases according to Neil (2004) can be 'specific to the particular situation' and its 'authority' can derive from: position, personality and knowledge. Male elders who are unanimously leaders in pre-European Igbo communities derive authority from their position as an aged member of the family believed to be endowed with much wisdom. Men achieved leadership status as they advanced in age. Age was explicitly associated with seniority and accumulated wisdom. The accordance of wisdom to the aged was literally attached to their accumulation of experience in interpreting traditions and customs of the land overtime. This serves as a prerequisite to the acquisition of leadership seat in the council of elders. Despite the unoccupied position of a king in most Igbo communities as earlier mentioned the positions of leaders were occupied by the elders whose style of leadership synchronises with the then system government - rulership by consultative assembly of the common people. This leadership 
Ezenagu: Leadership styles in the management of Igbo...

style of management would be examined while discussing the leaders of cultural institutions anchoring on their role in ensuring the longevity and preservation of cultural heritage.

\section{Council of Elders}

Igbo communities during the pre-European era had developed political institution under the governing authority of the council of elders. Supporting this assertion Nzomiwu (1999) affirms that the government of each Igbo community was in the hands of the elders (Ndiichie) whose permanent members were the family heads. According to Mr.Obiekwe (2015) "Izundiichie" (council of elders) comprises majorly Ozotitled men and selected men of integrity from some clans some who are family heads. The governance of these men was established on the principles of truth, one of the virtues for membership into the council. Clarifying the status of members of the council, Carlston (1968) indicated that membership of the council of elder includes apart from the heads of lineage group consists of rich influential men, certain titled holders and priests of important cults. In other words memberships of this institution are most times populated by titled holders comprising men empowered by tradition to address issues in the community. Although title holders were respected because of their accomplishments and capabilities, they were never revered as rulers, but often performed special functions given to them by such assemblies. The qualification of which is characterised by maturity of age, good knowledge of community traditions, in addition, to truthfulness which is a prerequisite virtue for title-taking making the position sacred. At the initiation rite these men took solemn vow to uphold without breaching and altering the traditions of the land. In Awka or Igbo land in general original dialect of the community reside on the lips of title men. They are custodians of everything that is sacred, customary and traditional in the community. As local legislators and judiciary officials of Igbo community, they do not make laws as modern legislators do rather interpret the culture to the understanding of all. The style of leadership adopted by these elders is basically democratic as Smock and Smock (1972) asserted that in ordinary everyday affairs the council of elders ruled by decrees but in matters of great moment the whole village or community had to be consulted. Adopting this 
measure ensured the continuity of Awka traditions which today are cultural heritage.

\section{Chief-priest}

Chief-priest is a leadership title associated with the traditional religion which connotes a spiritual leader. This is an institution in Igboland that is not in need of apprenticeship as Ogbalu (n.d) noted that there is no apprenticeship to priesthood, the male members of the priestly family or Umunna learn by observation of the elders and participation in worship from infancy. According to Mr.Nwaofor (2015) in Awka the position of priesthood falls mainly on the male folk in rare cases of female divinities are women (EzenwanyiPriestess) chosen an example is the Agbala-Imoka divinity, a goddess who oversees the affairs of women in the town.

The priest is not only the mediator between the two worlds (seen and unseen) of man but also custodian of shrine objects depicting the people's traditions. The shrine in this case is also a museum where cultural objects of ritual importance are preserved. The shrine does not only preserve cultural objects it also preserves cultural activities through its constant observance of cultural feast. Through this medium it informally educates the people on their traditions (Ezenagu and Oluwole, 2014). In view of this, the chiefpriest serves as an embodiment of the people's oral traditions in which capacity he manages the cultural heritage by seeing to the strict adherence of sanctions (taboos and abomination to which any breach requires an immediate cleansing). By so doing the sacred status of community is maintained and sustained.

\section{Traditional herbal Doctors (Dibia)}

The existence of diverse ailments and diseases requires the diagnosis of a physician otherwise a community could be wiped out by such. In cases of unproductive land, tolls of death, pestilence, incest, to mention a few which perhaps is far beyond the physical diagnosis of a physician requires spiritual diagnosis. The prevalence of these unforeseeably circumstances beyond human apprehension clearly portrays man's limitation and the sovereignty of the gods. In diagnosing such matters man sought the assistance of the gods. In African considering their religiosity, disease is one the afflictions 
from which man have sought release through curative medicine or protection through religion (Oduyoye, 1998). The man who offers the means of cure was considered to possess an usual quality, in the abstract this quality was wisdom, or part of it. Visibly, he possessed instruments of healing-medicine (Oduyoye, 1998) which is a gift from the gods. Any possessing such wealth of knowledge of the environment is referred to as traditional /herbal doctor (dibia). Also included in this category are Priests, the Rain-makers and Seers. In practice they possesses good knowledge of tree leaves, roots, grasses, sand, stones etc used for the preparation of medicine for curing of diseases, charms, amulets, talisman, invoking and holding rain among others. Such knowledge is a treasure to Igbo culture.

In Awka the practice of healing is an ancient act embedded in religion. Supporting the above assertion, Oduyoye (1998) emphasized that in antiquity where there was no separation of the practice of religion and medicine, a man of god was looked up to for healing (Naaman and Elisha; Jesus). With this background, the traditional doctor - dibia among the Igbo is not only a diviner but also a medicine man. He deals in drugs, most of which however, have spiritual rather than pharmaceutical value. He diagnoses the spiritual cause of disease and does not consider it as purely physical. By means of stones, bones or nuts he predicts the future, recount past and reveals culprits in cases of crime. Then with the use of leaves, roots and animals parts cures diseases. At presently herbal drugs are preferable to orthodox chemical drugs with numerous adverse side-effects. Thus, the leadership style used by leaders of this cultural institution is learning by participation. Usually such leaders require the aid of an apprentice. After some years of servitude the apprentice will be empowered to practice. The act of observance through participation has kept the knowledge of this institution alive till date.

\section{Family/Umunna}

The African family is the foundation upon which the uniqueness and continuity of the African race resides. Family in the African setting includes children, parents, grandparents, uncles, aunts, brothers and sisters who may have their own children, and other immediate relatives (Mbiti, 1970). In traditional African community the family 
is incomplete without a mention of the extended family - a collection of several primary (blood related) families that pool their strength and encourage each member's co-operation for the growth and development of their members (Mozia, 1982: 203). Put together various units of families constitute the African village, community etc. Through this basic unit of life, the Igbo retained their identifiable uniqueness as a people. As Okafor (1981: 39) rightly observed that, each Igbo family is the originator of its own conduct. The inevitable strength and weakness of the Igbo traditions anchors on the family. In other words the various families of Igbo traditional community are the pillar of cultural heritage because through the family, traditions are transmitted. Family elders ensure the continuity of culture by inculcating it in the children. Certain cultural skills run in some families such as basket weaving, pottery making, blacksmithing, traditional healing practices, etc. These skills are the indigenous scientific knowledge behind the success of indigenous technology. The family involvement in these industries affords children the opportunity to learn such skill by participant observation and apprenticeship. Analysing the efficacy of the family to Igbo community Ifemesia (2002) stressed that the family is the first agency for humanization and socialization in the Igbo person's life. It is thus the bedrock of every social and political community.

Therefore, having the family at the root of Igbo political organisation, it is generally constituted by members of the patilineage called Umunna (male folk). In Awka as in other Igbo communities family leadership was based on attributed power handed on as patrilineal birthright. The Umunna is a territorially kinbased unit which subdivides into compounds (Uchendu, 1965) and is made up of a number of extended families (Oguejiofor, 1996) headed by the eldest male member. The Umunna can be seen as one of the most important pillars of Igbo society following their allegiance in ensuring the longevity and continuity of family traditions. The leadership role of this group as caretakers of the family traditions promotes the preservation of Igbo cultural heritage.

\section{Umuada (Daughters)}

African culture though basically masculine oriented yet recognises the crucial position of women in the society. Women over the 
decades have immensely contributed to the social, economic, political and religious development of Africa. In Nigeria such role is eminent with the naming of the country by a woman following the success of the Aba women riot of 1929 in respect to the imposition of tax, to the international distinguished duties assigned to women by the Beijing China conference of 1995. The dignified role of women in society is thus not a recent phenomenon. In pre-European era Awka, women folk constitute recognised legal groups actively involved in matters militating against family life including economic, social, religious and political issues. Amidst the different Igbo communities of eastern Nigeria the women folk have established diverse forums popular amongst them is the "Umuada". The name "Umuada" is a compound noun which stands for daughters both married and unmarried in a clan but as is used in this paper refers only to married women folk within a clan. Umuada could also mean the daughters of the town who have married outside their town (Okparocha, 1998). Supporting this assertion Egboh (1987) further expatiated that the Umuada consists of all the women born in a particular village who are married to other village communities but form a local association of daughters of their land of birth communities. Though they are daughters of their original communities (families) yet, the Igbo tradition has vested in them enormous power to correct, discipline and deliver verdicts where necessary on individuals and groups of peoples. This group of women are the most revered among the Igbo people. They are given disciplinary and unquestionable authority by the Igbo culture to protect the peace and serenity in families.

The Umuada group plays an indispensable role in the preservation of Igbo cultural heritage. The leadership style adopted by this group according to Agbasiere (2000) is consultative voice. In Awka, this group of women possesses political power which gave them the authority to preside over important matters affecting families in the entire community. The decision reached by these women is considered final even by the Umunna respects. These women use their authority to protect and preserve the culture of the community from alteration. 


\section{Age-grade}

Igbo political organisations constitute different structures one of which is the age-grade (Otu-Ogbo) system. It comprises members within an acceptable age range. This varies from one community to another. Age grade refers to a group of persons having an age relationship of a wider span of years informally brought together through social, political and ritual functions in the society in which they are part (Egboh 1987). The age span within every age grade society is typically five years. In exceptional circumstances they would admit someone that is slightly older or younger by a year or two.

The age grade system of Awka is an active social institution which affords the youth the opportunity to use their youthful exorbitant in ensuring the continuity of community traditions. In Egboh (1987) view one of the sole objectives of the age-grade is to develop the consciousness and a strong sense of membership of oneness among the Igbo community. It is one of the associations that give individuals some sense of belonging and a sense of collective responsibility and contribution towards the general development of the society. They also played the role of guard - traditional role of policing the community and enforcing law and order. Therefore all males as Ogbalu (n.d) noted perform certain duties. In most ancient cities of Nigeria for instance the old Benin and Kano Empire respectively, it is this group of able bodied men that were used in constructing the ancient walls to protect the community from enemy invasion. These walls are today national monuments considering their historical significance. Similarly, in Awka these groups of able bodied young men most time ensure proper execution of community traditions. They bring defaulters of traditions to book and guard the community against invasion. Also they play active role during traditional feasts guarding against obnoxious behaviours. Therefore, they are indispensible actors in the process of the management of Igbo traditional legacy.

\section{Masquerade cult}

Masquerades (Mmonwu) are very fundamental to traditional African society (Ezenagu and Olatunji, 2014). In Awka community, the masquerade is an actor or performer whose personal identity is 
physically concealed, and to whom another identity is attributed in the world of spirits in the direction analogously indicated by its shape or by the form of physical performance (Onyeneke, 2000). In some places, they are believed to be the dead ancestors and messengers of traditional deities from the supernatural world (Ezenagu and Olatunji, 2014). Therefore, the spirits of the ancestors through masquerade are understood as making fresh and temporary appearance among the living. This concurs with most scholarly opinion that masquerades are spirits of the ancestors regarded as "the living dead". Adedeji (1998) noted that the Yoruba adopted the masquerade as a religious phenomenon and believed its realization to be the materialised spirit of an ancestor. While Wambutda (1998) from his study of Dungun village noted that ancestors can appear in guise of masquerade. Further Adedeji (1998) stated that beginning from the seventeenth century, the egungun - masquerade became a great religious association which formed an important part in the political life of the Yoruba

In traditional Awka community, the masquerade institution functions as a cult hedged about with secrets open only to initiates believed to be the source of its strength and weakness. Once divulged into by the female folk loses its masculinity. The deception embedded within the fringes of this institution is further broadened with the masking of individual members. Initiated members are usually clothed with the masquerade regalia during important cultural events in the community. The masquerade regalia are considered sacred as some of the masks are replica of the emblems of the gods thereby the person behind the mask must not be unmasked by anyone calling out his name. Upon disclosure the culprit and masked initiate were severely punished.

The art of masquerade has long been a classic African expressive form, replete with meaning and cultural importance. The carvers design the masquerade masks reflecting a portion of the community life. The mask itself is an emblem of the community. They serve as the visible expression of a spiritual force that validates the basic beliefs of a society, and reinforce acceptable social modes of conduct and symbolise the spiritual authority that eradicates social evils (Booths, 1977). In Onyeneke (2000) view masquerade serves as village police. They are also entertaining characters of 
ancient African communities likened to the comedians and clown of modern age (Ezenagu and Olatunji, 2014). DuringImoka traditional festival in Awka, masquerades of various sizes and status usually parade the town entertaining people. The loyalty of masquerade initiates' in concealing the mystery of the cult was instrumental to the preservation of institution. The leadership style adopted by leaders of the sacred institution was participative-style involving all the initiates in maintaining the status-quo of the institution.

\section{Challenges of Igbo cultural heritage}

Nigeria is a multi-ethnic nation with unique ways of life showcased through the display of distinct cultural heritage. This could be seen in its myriad of indigenous languages, cultural practices, norms, folklores, traditional knowledge, technologies, etc (Ezenagu, 2015: 126). These heritages are threatened by external forces of westernization. The westernization of Nigerian society started with colonization - an act of subjugation under colonization and ended producing Nigerians with western culture. To these new Nigerians African culture is substandard as a result should be replaced. Based on this, it is no gainsaying that one of the most profound legacies of colonialism was inferiorisation of African indigenous cultures and the deliberate attempt to gradually replace them with western values (Ezenagu and Oluwole, 2014). As Adesina (2005: 405) posits that "with the condemnation of everything African and introduction of everything European", Igbo cultural heritage which is a summary of the past activities and accomplishment of the race stands the chance of extinction despite its value. However, westernization was not the problem rather it vestiges namely - Christianity, education, mode of interaction, value system, etc. The Christian religion was the early missionaries' instrument of conversion from African traditional religion. The conversion to Christianity was with a price paid at the expense of indigenous culture. The early African Christians were indoctrinated to reject everything traditional and accept everything Christian. On this note, they believed the misjudged opinions of the early missionaries of their traditions which were mocked with derogatory terms such as barbaric, heathen, satanic, etc. These derogatory terms made it easy for Awka people to quickly embrace everything the Christian faith stood for. This had untold 
consequences on the arts and craft heritages as the people with their own hands made burn fire of traditional museums (shrines) and art works kept therein. Indirectly the artisans lost their relevance in the community. Thereafter, these missionaries whose words led to the destruction of traditional paraphernalia sort dearly for the so-called idol objects following its high demand in the western world on the basis of their intrinsic qualities. Hence, it is not surprising that Awka artistic heritage portrays a civilization perhaps too sophisticated for the primitive African mind according to early European scholars to conceive or apprehend (Ezenagu and Olatunji, 2014). This accounted for the reason why the missionaries looted African shrine objects. They further noted that the unique and awe inspiring nature of Nigerian artistic heritage opened the flood gate of tourists and researchers visiting museums were the objects were kept. In nearly all museums in Nigeria visitors marvel at the skills of the producers of Nigerian art heritage.

Education in pre-European Awka town was basically informal even with the absence of a proper classroom with walls. In view of this, Mr.Anaje (2015) vehemently stated that in Awka children are educated in African style. According to him education takes place everywhere, knowledge is acquired in the home, farm, workshop (blacksmith, weaving, carving and pottery) etc. The absence of a constructed classroom was never a hindrance to learning as learning takes place within different settings and scenarios. One of the instruments of learning at this time was through apprenticeship usually appraised with experience rather the usual examination of western model. Though books were not used yet the literary works of the people constitute the books from which traditional norms were taught. It is therefore imperative to note that it was through traditional education that the culture, traditions and experiences were transferred from generation to generation which also enabled them to explore and exploit their environment (Olagunju, 2005). The colonial masters' could not fathom the efficacy of this educational process thus enforced the enrolment of people into western model schools. The enlightenment that came with western education could not fuse well into the Nigeria worldview consequently, it eroded the traditional confidence and pride which is the root of cultural integration (Ezenagu, 2015). This 
led to the degradation of Igbo cultural heritage which was nothing compared to western heritage consequently was neglected.

Imbibing the political organisation of the western led to introduction of a permanent ruler or king to oversee the affairs of the community. This system destructed the polity of Igbo community which affected its heritage. With the absence of a consensus ruler in then Igbo community, the council of elders delegated authority to certain persons in charge of social institution which constitute its cultural heritage. The adoption of kinship with perhaps autocratic leadership styles abolished previous ruling heads along with the democratic leadership style as a result most social institutions headed by these persons became less effective in the community. One of the institutions greatly affected is the masquerade cult. They have lost most of their functions as police of the community. Youths use the masquerade regalia to rather molest young girls and women. Although today young men parade in masquerade regalia yet the processes of initiation and the secrecy of the cult have to a great length been abused by the same people for lack of knowledge of the traditions of the cult.

Furthermore, the activities of indigenous technologies during the pre-European era were quite remarkable considering the uniqueness of the products. These industries constitute an important aspect of Igbo cultural heritage passed on from one generation to another. These industries had been in existence "for thousands of years prior to the coming of the Europeans with their "civilization mission", the people of Nigeria had their indigenous industry and had unique and commendable skills in bronze-casting, ivory and wood carving, iron-working, basket-making, blacksmithing etc" (Lawal, 1987: 113). The above named Igbo traditional technologies declined with the introduction of factory and importation of western products. These traditional technologies were long standing heritage of the people which served as a means of providing sustenance. The introduction of factory opened the gate of cheap labour. In Ezenagu (2014b) opinion the presence of white collar job displaced the possibility of youths' craftsmanship in Blacksmith or any other indigenous industry considering the tedious nature of the tasks assigned to apprentice. The decline of this industry could be traced according to Ezenagu (2014b) to the crude and tedious processes of 
indigenous technology which facilitated its replacement with the refined and simpler processes of Western technology. The autocratic leadership styles of the colonial masters favoured the importation of foreign finished goods. The appeals of these goods were no match for the traditional produced goods as a result people choose the foreign products over locally made goods. All these challenges coupled with the death of skilled traditional practitioners and the urban migration of practitioners' children threatens the viability of indigenous technology. Thus in bid to hold on to modern technology African lost hold of its indigenous technology (Ezenagu, 2014b). All these challenges besetting the continuity of Igbo cultural heritage arose with the displacement of the democratic leadership style of management of pre-European Awka town with the colonial autocratic-style in addition to the post-colonial unstable leadership style of alternated military and democratic styles respectively. Consequently, Igbo cultural heritage have been swept up into the tide of change which poses a huge threat to the historical understanding of the race.

\section{Conclusion: The future of Igbo cultural heritage}

Igbo cultural heritage stands as the people's cultural identity without which the race draws near to extinction. Thus, the relevance of preserving these heritages is tantamount to continuity of the race. It is then the responsibility of each generation to sustain the authenticity of the heritage and transfer it to other generations. The sustainability of the authenticity of these heritages has been studied from different perspective. However, this study considered the leadership styles adopted in the management of Igbo cultural heritage in pre-European era. This was one of the factors responsible for the preservation of the real essence of Igbo cultural heritages as necessary platform for sustaining Awka cultural identity. Considering the stateless status of pre-colonial Igbo communities of south eastern Nigeria the political organisation was largely ruled by the general consensus of council of elders. This leadership style was rooted in consultative voice of democracy which employed the active participation of community members in community affairs. The effectiveness of this style actually accounted for the survival of Igbo cultural heritage of today. The various leaders of cultural 
institutions had the goal of passing the same tradition unadulterated to other generations. Considering Awka loyalty to its traditions Mr.Okafor (2015) stated that it is a taboo for the traditions of the land to vanish within a generation knowing this Awka community guard their traditions jealously with pride.

Consequently, at presently, the leadership style changed with the coming of the Europeans through which western culture was introduced to sniff out the traditions of the land. However, through education and enlightenment the Nigerian government saw the relevance of cultural heritage and efforts were made to protect them. Such efforts led to the establishment of various cultural institutions not limited to NCMM (National Commission for Museums and Monuments), CAC (Council for Arts and Culture), CBAAC (Centre for Black and African Arts and Civilization) etc. With these institutions tangible cultural heritages were documented and preserved for posterity in the museums. The tangible immovable heritages with unique historical legacy were declared national monument to protect them from alteration and maintain their essence. While the intangible heritages such as folklore, norms, values, constitute bulk of today literary novels used in schools at all levels intimating Nigeria with their traditions. Traditional events packaged as tourism product. Conclusively, despite the Europeanization of the Africans, Igbo cultural heritage strive tilldate as markers of cultural identity and national pride.

*Ngozi Ezenagu, Department of Tourism and Events Management, Afe Babalola University, Ado-Ekiti, ngoezenagu@gmail.com 
Ezenagu: Leadership styles in the management of Igbo...

\section{References}

Achebe, C. (1965) Things Fall Apart, London: Heinemann Books

Adedeji, J. A. (1998)Egungu in the religious concept of the Yoruba. In E. A. Adegbola (Ed.)Traditional Religion in West Africa, Ibadan: Daystar Press.

Adesina, O. A. (2005) European Penetration and Its influence on African Culture and Civilization. In Ajayi, S. A., (ed.) African Culture and Civilization, Ibadan: Atlantis Books

Agbasiere, J. T. (2000) Woman in Igbo life and thought,London: Routledge.

Anyanwu, U.D. (1995) Kingship and leadership in Igbo culture: A historical portrait. In G.O.Oguntomisin and S. Ademola (Eds.) Reading in Nigerian history and culture, Ibadan: Hope.

Bass, B. (1989)Stogdill's handbook of Leadership, New York: The Free Press

Beugré, C and Offodile, O. (2001) Managing For Organizational Effectiveness In Sub-Saharan Africa: A Culture-Fit Model, International Journal of Human ResourceManagement, vol. 12, no. 4, pp. 535-550.

Burns, J.M. (1978) Leadership, New York: Harper Torchbooks Booth, N. S., (ed.) (1977) African Religions: A Symposium, New York; NOK Publishers

Bosiok, D (2013) Leadership styles and creativity, Journal of Applied Knowledge Management, vol.1, issue 2, pp63-77

Carlston, K. S., (1968) Social Theory and African tribal Organisation, Chicago: University oflllnois Press

DuBrin A. J. (2001)Leadership: Research findings, practice, skills, 3rd ed., Boston: MA, Houghton Mifflin

Egboh, E. O. (1987) Community development efforts in Igboland, Onitsha: Etukokwu Press

Ezenagu, N. (2015) Material Culture and Indigenous Technology. In Ademowo, A. J and Oladipo, T. D., (ed.) Engaging the Future in the Present: Issues in Culture and Philosophy, Ibadan: Hope Publications, pp122-137

Ezenagu, N. (2014a)Galvanising Culture for Nigeria's Development, in Agidigbo: ABUAD Journal of Humanities, Vol.2, No.2, pp87-96 
Ezenagu: Leadership styles in the management of Igbo...

Ezenagu, N.(2014b)The Blight of African Indigenous technology in the $21^{\text {st }}$ century: The way forward, Journal of Tourism and Heritage Studies, Vol.3, No.1, pp 59-73

Ezenagu, N and Olatunji, T. (2014)Harnessing Awka traditional festival for Tourism promotion, Global Journal of Arts, Humanities and Social Science, Vol.2, No.5, pp. 43-56.

Ezenagu, N and Oluwole, A. (2014)Domesticating the African Museum for National Development, African Journal of Stability and Development, Vol.8, No.2, pp55-64

Ifemesia, C. (2002)Traditional humane living among the Igbo: An historical perspective,Enugu: Fourth Dimension Publishers.

Ingo, W. (2010) Contemporary Leadership Theories: Enhancing the understanding of the Complexity, Subjectivity and Dynamic of Leadership, Denmark: Physica-Verlag

Kaiser, R.B. and DeVries, D.L. (2000) Leadership styles.In W.E. Craighead and C.B.Nemeroff (Eds.) TheCorsiniEncyclopedia of Psychology and Behavioral Science (3rd ed.). New York: Wiley \& Sons

Kast, F. E and Rosenzweig, J. E. (1981)Organisation and management: A system andContingency Approach, Maidenhead, New York: McGraw-Hill

Khan, M.A. (2010)Evaluating the Deming Management Model of Total Quality in Telecommunication Industry in Pakistan - An Empirical Study, International Journal of Business and Management, 5 ( 9), 46-59.

Kippenberger, T. (2002)Leadership styles, Oxford: Capstone publishing

Kets de Vries, M. (2001)The Leadership Mystique: A user's guide for the human enterprise, Financial Times Prentice Hall, 2001.

Lawal, A. A. (1987) Industrialization as Token. In Falola, T., (ed.) Britain and Nigeria, Exploitation of Development, London: Zed Books

Lester, C.N. (1975)Leadership styles: A key to effectiveness, Journal of Extension, Nov/Dec., pp3-11

Lewin, K., Lippitt, R., and White, R. K. (1939)Patterns of aggressive behaviour in experimentally created social climates, Journal of Social Psychology, 10, 271-299 
Ezenagu: Leadership styles in the management of Igbo...

Likert, R. (1967) The Human organisation: its management and value, New York: McGraw-Hill

Lussier, R., and Achua, C. (2009) Leadership: Theory, application and skill development, Mason: South-Western Publications

Mbiti, J. S. (1969) African Religion and Philosophy, New York: Praeger Publishers.

Mozia, M. (1987) Solidarity in the Church and solidarity among the Igbos of Nigeria: An anthropologico-theological study, Ibadan: Claverianum Press.

Nahavandi A. (2002)The art and science of leadership, 3rd ed., Upper Saddle River: Prentice Hall

Nzomiwu, J. P. (1999)The concept of justice among the traditional Igbo: An ethical inquiry,Awka: Fides.

Oduyoye, M. O. (1998)The Medicine Man, the Magician and the Wise man. In Adegbola, E.A., (Ed.) Traditional Religion in West Africa, Ibadan: Daystar Press.

Okafor, F. (1992)Igbo philosophy of Law, Enugu: Fourth Dimension Publication

Okparocha, J. (1998)IriJi - The New Yam Festival. In E. A. Adegbola (Ed.) Traditional Religion in West Africa, Ibadan: Daystar Press.

Ogbalu, F. C. (n.d) Igbo Institutions and Customs, Onitsha: University Publishing Company

Oguiofor, J. O. (1996) The influence of Igbo traditional religion on the socio-political character of the Igbo, Nsukka: Fulladu

Oladipo K. S., Jamilah O., Abduldaud S., Jeffery L. D. and Salami D. K. (2013)Review of leadership theories and Organizational performances, International Business Management Journal,7(1), pp50-54.

Olagunju, A. M. (2005) Traditional System of Education in Africa. In Ajayi, S. A., (ed.) African Culture and Civilization, Ibadan: Atlantis Books

Omolayo, B. (2007) Effect of Leadership Style on Job-Related Tension and Psychological Sense of Community in Work Organizations: A Case Study of Four Organizations in Lagos State, Nigeria, Bangladesh e-Journal of Sociology, 4(2)

Onyeneke, A. (1987) The Dead Among the living: Masquerades in Igbo Society, Nigeria: Asele Institute 
Ozo-Eson, P. I. (2012) African Society and Culture our Heritage, Abuja: Ugwu Printing and Publishing

Smock, D. R and Smock A.C. (1972) Cultural and political aspects of rural transformation: A case study of eastern Nigeria, New York: Paeger

Stogdill, R. M. (1974) Handbook of leadership: A survey of theory and research, New York: The Free Press

Thomas, N. (2004) The John Adair Handbook of Management and Leadership, India: Replika Press.

Uchendu, V. C. (1965)The Igbo of South-East Nigeria, New York: Holt Rinehart and Winston

Wambutu, D. (1998)Ancestors - The living Dead. In Adegbola, E.A., (Ed.) Traditional Religion in West Africa, Ibadan: Daystar Press.

Warriner, C. K. (1955) Leadership in Small Group, American Journal of Sociology, 60, 361-369

\section{Oral Interviews}

Mr.Anaje, retired driver (75 years) 03/01/2015

Mr.Obiekwe, Trader (68 years) 01/02/2015

Mr.Nwaofor Old trader (traditionalist) (76 years) 05/01/2015

Mr.Okafor, Retired civil servant (67 years) 03/01/2015 